\title{
Effects of Information and Communication Technology and Social Media in Developing Students' Writing Skill: A Case of Al-Quds Open University
}

\author{
Dr. Aida. M. Bakeer \\ Assistant professor \\ Al-Quds Open University \\ Palestine
}

\begin{abstract}
This paper presents a case study of using Information and Communication Technology ICT and social media in a writing course at Al-Quds Open University (QUO). The researcher aims to explore undergraduate EFL learners' writing problems, and the effect of ICT and social media in developing positive attitudes and improving students' proficiency in writing English at the university level. Technology integration is becoming increasingly popular in the pedagogical field due to the wide spread of ICT tools and the availability of the internet. ICTs and social media were used in parallel with traditional teaching methods of teaching writing. The sample of the study consisted of 72 undergraduate students divided into a control group and an experimental group. Students' attitudes were compared between the two groups to measure the potential of available technology and social media to develop the writing skill. The findings of the study showed that the integration of ICTs and social media had a positive effect in developing students' writing skill. Additionally, the undergraduates show satisfaction with the potential achievements of integrating ICT and social media in developing the writing skill.
\end{abstract}

Keywords: e- learning, teaching writing, attitudes, social media, ICT, language learning.

\section{Introduction}

English is the official language of the world. However, the traditional methods of teaching English in Palestine reduced English language learning to mechanical memorization and miserably fail to develop language competency among the students as it depends largely on lecturing and is mostly done in the traditional chalk-andtalk way, (Farrah \&Tushyeh, 2010). These stereotyped methods and teaching material makes the learning a monotonous activity and creates distaste among the students by reducing them to mere passive receptors of language and not active participants in the learning process, (Sumathi, \& Phil, 2016). Students have little chance to use English in communication and limited exposure to academic English, therefore, they are often unable to fully comprehend lectures or actively participate in class discussions. Many are also hampered in their ability to express themselves in writing, (Kurzweil Educational Systems, 2004).

Teachers' practices with unmanageably large class sizes in schools, virtually no resources, unreliable Internet access, traditional methodological approach focusing on rote learning and repetition, leave little room for participation, and the cognitive development of the students, and result in a local population which has generally poor communication skills in English, (Dajani, 2014). Dwaik (2016). In addition, teaching English through the medium of Arabic - students' native language- is also a serious impediment to improving students' English skills, (Adas \& Bakir, 2013).

Writing is one of the four language skills that requires a special attention. It is a significant skill in language production, (Fareed, Ashraf and Bilal, 2016) as its role is to convey the message accurately and effectively, and its proficiency plays a major role in communication,(Bancha, 2013). Writing is the most challenging area in learning the second language (Dar \& Khan, 2015).University students are neither knowledgeable nor skilled enough to feel confident to communicate efficiently and effectively, using English as a foreign language. Language teaching has a number of dimensions, which include the development of oral expression, written skills, literature, and creativity, (Irish National Teachers' Organization, 2004). However, Adas \& Bakir (2013), noted that students do not write very often and most of what they write is classroom-bound. The most important factor in writing exercises is that students need to be personally involved in order to make the learning experience of great value and make learning more meaningful and more exciting. 
Prakash (2015), argued that professional learning is important to master these challenges, taking advantage of the opportunities, and making sustainable improvements in student learning. Ongoing, high-quality professional learning for teachers, educators, and administrators can help: empower educators to develop competence and confidence in working with new learning models, curriculum resources, assessment methods, tools, and technologies; enable students to benefit from a student-centered $21^{\text {st }}$ century education, and ensure that technology investments are used to achieve programs' goals.

\section{Review of Literature}

English is our window to the world, and its paramount importance as a means of communication with the international world necessitates using modern and innovative materials and techniques of teaching to face the challenges and difficulties students encounter, and overcome the dissatisfactory low levels of English language proficiency as an academic language, (Barri, 2017; Dajani, 2014, Ramahi, 2015; Bianchi\& Abdel Razeq, 2016). Improving educational outcomes will require efforts on many fronts. Educators have been developing and evaluating easy-to-use learning techniques and tools that could help students achieve their goals, meet the individual needs (Pim, 2013; Wilson, 2015), and empower them with lifelong learning. To meet the needs of the $21^{\text {st }} \mathrm{C}$ skills, there is a demand to promote students' skills and participation, enrich love of learning, empower students with lifelong learning and enable individuals to realize their full potential. Ministry of Education (2015), confirmed that it is not enough to have knowledge; students must use knowledge in real-life situations.

Therefore, learning how to write has gained considerable importance for the last two decades forits use as a tool for effective communication of ideas, and in research work (Dar \& Khan,2015). It is based on appropriate and strategic use of language with structural accuracy and communicative potential (Mahboob,2014). Writing is a cognitive process that tests memory, thinking ability and verbal command to successfully express the ideas because proficient composition of a text indicates successful learning of a foreign language (Alfaki,2015; Perkins, \& Smith,2014).

Fareed, Ashraf and Bilal (2016), discussed the factors that hinder the development of undergraduate ESL learners' writing skills. They stated that writing is not given much importance in our society. It is considered as a secondary skill to speaking and remains ignored. Students have never been given the idea that they need to be good writers. Writing does not get maximum of instruction. Writing is one of the skills which is least liked in their society. Similarly, the examination system does not encourage learners' creative writing. Instead, it encourages memorization and plagiarism. In addition, the examination system does not encourage students to be analytical or critical. Teachers give them short time to write, and encourage them to memorize. Writing anxiety is also considered to be a hindrance in learners' production of well-organized text. There is so much tension and anxiety that gives mental difficulty to write.

Al-Quds Open University (QOU), as a pioneer in e-learning in Palestine, emphasizes the integration of the most recent and effective facilities and methodologies of teaching, learning, research, and best practices in higher education with an emphasis on the concept of e-learning for freedom, equity and equality in learning as the right of education.

\subsection{Technology in Education}

Nowadays, college students have been surrounded by and permanently connected with information technologies. Moreover, they interact with digital media almost everywhere, and using those media becomes a second nature, . In short, they take technology for granted as a central part of their lives, (Jung, 2006), ICTs have become within a very short time, one of the basic building blocks of modern society. Although no technology is meant to replace the teacher, the rapid breakthroughs in new information and communication technologies ICTs will further change the way knowledge is developed, acquired and delivered. Platforms like Facebook, LinkedIn and Twitter are used by almost everyone. Social media is about collaborating, networking, sharing and generating knowledge and content, and all of these features are of great value in the context of higher education, (Gupta, 2015).

Social media is the social interaction among people in which they create, share or exchange information and ideas in virtual communities and networks. Social media is defined as "a group of Internet-based applications that build on the ideological and technological foundations of Web 2.0 and that allow the creation and exchange of usergenerated content. Social media are considered as enablers of lifelong learning that can be used as tools bridging formal and informal learning contexts (EACEA, 2013). 
Furthermore, social media depend on mobile and web-based technologies to create highly interactive platforms through which individuals and communities share, co-create, discuss, and modify user-generated content. They introduce substantial and pervasive changes to communication between organizations, communities, and individuals, (Rajesh \& Michael, 2015).

It is argued that social media has the potential to bridge formal and informal learning through participatory digital cultures. The educational benefits of appropriating social media into learning contexts are contested. Research on social media in education suggests that integrating social media in learning and teaching environments may yield to new forms of inquiry, communication, collaboration, identity work, information and resource sharing, or have positive cognitive, social, and emotional impacts (Greenhow\& Lewin, 2015). Social media helps professors to be connected to their students off campus as well as with their ex-students. Professors use social media as a way of teaching by creating groups and accounts for students where the information can be accessed, (Gupta, 2015).

Rajesh \& Michael, (2015) indicated that social Media Networks are growing and it's been reaching to large people day by day. They found that students can make use of the interaction services, blogging services, group services in their studies. Traditional lecture formats are one way and obviates the need for emphasis and clarification as there are generally time constraints on delivery and/or there is no formal feedback mechanism. A social network can facilitate learning by allowing for prolonged interaction between the provider of the education and the recipient of the education which has the effect of reinforcing the information provided before the recipient progresses, (Vervaart 2013).

Jiménez (2014), indicated that higher education institutions should lead in drawing on the advantages and potential of new ICTs, ensuring quality and maintaining high standards for education practices and outcomes in a spirit of openness, equity and international co-operation; new technologies offer opportunities to innovate on course content and teaching methods and to widen access to higher learning. Dabbagh \& Kitsantas (2011), investigated the relation between self-regulated learning and social media; they stated that as social interaction happens in the classroom, interaction is happening in the media, and this helps students experience the formal learning in an informal side of input. They describe the out coming of social media as a "highly self-motivated, autonomous, and informal" way of learning.

\subsection{Rationale for using ICTs and social media in teaching/learning English language}

Technology is used in language learning to improve efficiency, increase creativity and taking risks, and to help students gain confidence and independence (Genlott \& Grönlund, 2013). Nomass, (2013), argued that sing ICTs facilitates student's interaction and communication and enables them to use language for real purposes and in real contexts. He added that ICT enhances motivation and makes learning language faster. ICT both supports and integrates literacy skills. It enhances interactive teaching and learning styles and provides many opportunities for creativity; develops curiosity about how languages work, raises the level of cognitive challenge, extends students' ability to be independent in their use of the new language, and creates communities of learning, where students can practice English language skills, (Alfahadi,2017).

Ghasemi \& Hashemi, (2011), indicated that learning tasks has shifted towards the learners and this has dramatically changed the roles of teachers. They added that ICT tools enhance interactive teaching and learning styles and provide many opportunities for creativity. When used imaginatively they can stimulate curiosity about how languages work, raise the level of cognitive challenge, and extend students' ability to be independent in the use of the new language. ICT offers a powerful way of enabling students to be fully engaged in their own language learning process, to promote creativity and collaboration.

ICT has the potential to increase the percentage of learning that involves the traditionally more difficult literacy skills by maximizing exposure to the written word, and supports understanding and recalls in the new language. It can certainly enhance the expected desirable goals, (Akinwamide, 2012). ICT helps English Language Learners by enabling them to communicate, edit, annotate and arrange text quickly and flexibly, (Ghasemi \& Hashemi, 2011).

Jiménez (2014), in his study examined the role of information and communication technologies in language teaching. It has been clarified that ICTs are not necessarily meant for "in class use"; they support the language learning experience in out of class environments as well. Through an electronic survey, Jiménez investigated the opinions of fifty ex-students of the B.A. in the Teaching of English at the University of Costa Rica, and analyzed 
the collected data. The results showed that information and communication technologies play an essential role in language learning to develop the macro linguistic skills.

Sámano (2014), suggests not that English or any other language can be learned entirely through social media platforms, but it can be considered as a tool for creating a good learning environment and a space for practice in an informal context. Social media also allow enhance of topics because they develop self-motivation on topics seen in class which, in a snowball effect reinforces skills like written expression and creativity. The results indicated that social media create a good learning environment and that teachers can take advantage to reinforce topics seen in the classroom. Sámano found that $78 \%$ of teachers believe that social media improve their students' English.

Alfahadi(2017), in his study aimed to investigate how social media sites can improve English language skills among Tabuk University students and to determine what the most common social media sites are that the learners use in order to practice English language skills. The researcher concludes that social media sites can be incorporated in the EFL syllabi as teaching and learning aids because they contain a huge combination of sound, text and videos where students can comment and get direct remedial feedback.

On the other hand, researchers have warned against leveraging social media for learning. Kirschner and Karpinski (2010) found that time spent on Facebook negatively affected college grades. Similarly, Junco and Cotton (2013) examined how students multitask with Facebook, and found that using Facebook while doing schoolwork was negatively associated with their overall grade point average.

\subsection{Technology for developing writing skill}

Dhanya (2016), clarifies that the teacher is no longer the sole source of content, and the students are able to shape their learning in ways which align closely with the needs of their daily lives. All the above encourage the user to engage with information in English, reading and writing both formally and informally. The use of these techniques can act as a bridge to facilitate communication inside and outside the classroom. These devices can be a powerful teaching and learning device too.

Khan, Ayaz \& Faheem (2016), in their descriptive study investigated the role of social media in English language vocabulary development at university level. The sample consisted of 36 University Teachers selected via random sampling technique. They concluded that social media role is dominant in vocabulary development of English language at university level. The role of social media in English language vocabulary development is like the brightness of the day because social media facilitate the English learners to learn new words and phrases and to improve their vocabulary. Social media plays a dominant role in English language learning because it provides opportunities to the English language learners to improve their writing, reading, and similarly, to read new text and phrases to improve their vocabulary. Educators have found that software tools can be extremely beneficial in addressing the needs of English Language Learners. The unlimited exposure to academic, business and technical texts provides opportunities to increase learners' fluency and comprehension. Text-to speech software can be used alone, or as an enhancement to special purpose programs already in place.

Social media provide English Language Learners with choices of when, where and how to study and enables them to take charge of their own learning by focusing on content instead of struggling with the mechanics of reading and writing English. It is added that English Language Learners often have difficulty expressing their thoughts and ideas clearly in writing. Kurzweil Educational Systems (2004). A number of Kurzweil 3000 features make it easier to compose, edit and proofread written work including: converting highlighted text into an outline as a starting point for writing, using word prediction to improve vocabulary selection and spelling, using the thesaurus to substitute alternate words to make writing more interesting, using dictionary and spell check to facilitate proof reading, listening to written work to correct awkward sentences, missing words, or incorrect tenses, and referring to customizable lists to clarify the correct usage of confusable words and homophones.

Purcell, Buchanan, and Friedrich (2013), conducted a survey on 2,462 advanced placement and national writing project teachers. They find that digital technologies are shaping student writing in myriad ways and have also become helpful tools for teaching writing to middle and high school students. These teachers see the internet and digital technologies such as social networking sites, cell phones and texting, generally facilitating teens' personal expression and creativity, broadening the audience for their written material, and encouraging teens to write more often in more formats than may have been the case in prior generations. 
Sakkir, Rahman \& Salija (2016), in their study examined students' perceptions of the use of social media in the process of teaching English in a higher institution in Indonesia. Findings from this study indicate that the majority of students showed a positive attitude toward and a willingness to use social media in the writing classroom. However, factors such as large classes, lack of training on the use of the Internet, and the lack of facilities could be possible barriers to the use of social media in the classroom.

\section{Statement of the Problem}

Contemporary young people are commonly designated as digital natives characterized by habitual use of ICT in everyday life (Slechtova, 2015). Nevertheless, the current education environment demands more integration of ICT tools in higher education institutions in Palestine, focusing on the use of new media which is crucial in developing and generating skillful students who can confidently gain a competitive edge in the age of information and communication technology. To what extent do ICT and social media in a blended learning environment promote students' positive attitudes towards learning English, and develop their performance as solutions for the dissatisfactory achievements in the writing skill?

\section{Significance of the study}

The use of ICT and social media in education is still in its infancy in developing countries and in Palestine. The significance of this research is to address the challenges and difficulties that face students majoring English when learning writing courses at QOU. It also aims to shed light on the effect of using social media and ICT tools on students' motivation and attitudes towards language learning, and on enhancing students' linguistic competences and excellence in the writing skill by identifying the role of social media in writing development at the university level.

\section{Research Questions}

This study attempts to answer the following questions:

1. What are the challenges and difficulties that face students majoring English in learning writing skill?

2. What are the attitudes of undergraduate students regarding the use of social media in writing English language at university level?

3. Do students in the experimental group develop their proficiency in writing better than those in the control group with face-to-face traditional teaching method?

4. How do learners in the experimental group perceive the potential achievements of integrating ICT and social media in developing their writing skill?

\section{Methodology}

This research is an experimental research that aims to survey and address the challenges that face students majoring English at QOU in writing courses. Also, it aims to evaluate the differences of students' attitudes and writing proficiency under the effect of integrating ICT tools and social media in a writing course. This includes a pre-test, the treatment and implementing the new method, and a post-test.

\subsection{The subjects of the study:}

The subjects of the study consist of all students majoring English, and enrolled in the academic English course 'writing 2' in Nablus branch during the academic years 2017-2018. The sample of the study consisted of 72 undergraduate students distributed into two sections deliberately selected from Nablus branch in the North area of Palestine as it is one of the largest branches of QOU. The students were divided into two groups: a control group (40 males and females) and an experimental group (32 males and females). The control group was exposed to the traditional method of teaching, but the experimental group had the advantage of using the available ICTs and social media (the treatment) in addition to the traditional method.

\subsection{Instrumentation:}

To achieve the purposes of this research paper, the researcher will prepare the following instruments:

1. An attitudinal questionnaire

2. Pre-tests to be applied before the treatment

3. Post-tests to be applied after the treatment 
The attitudinal questionnaire is a scale comprised of 25 items under five subscales namely motivation to write, potential of technology, comparative use of technology, creativity, and potential of development. The items followed Likert scale of five responses, and were scored as Strongly agree $=5$, Agree $=4$, Not sure $=3$, Disagree $=2$, Strongly disagree $=1$. The overall score yields students' attitudes towards the ICT and social media. The scale was found to be reliable (Cronbach's reliability co-efficient on the overall scale measured 0.72 ) and valid.

4. The treatment: the design and implementation of flexible student-based activities that allows ICT and social media integration, peer-review, and self-assessment.

\subsection{Procedure}

The research instrument was administered on the undergraduate students. Pre-test and the attitudinal questionnaire were applied to students in both groups at the beginning of the course and before implementing the research tools. Students in the experimental group were exposed to the treatment, e-learning materials, virtual classes, and they use email, chat groups, What's app, and Facebook to discuss issues pertaining to their studies with colleagues, and do activities. Students were encouraged to use ICT and social media on daily bases as a habit. They called the group morning thoughts, which consist of writing pages done every day. It can be about anything that pops into their heads, in addition to any work related to the academic course. Peer review, discussion, instructor comments and feedback, and self-assessment were adopted; students were encouraged to evaluate and modify their work to develop the quality, and communicate with each. The researcher's role was to control, guide, review, edit, give feedback, and encourage the students participate and work. In the end of the course, a post-test and the attitudinal questionnaire were applied to students in both groups. Students in the experimental group were asked about their views towards the potential achievements of ICT and social media in developing the writing skill. The data was collected personally by the researcher. The collected data was computed and analyzed using SPSS to answer the questions of the study.

\subsection{Limitation of the Study}

This research study is limited to students majoring English in Nablus branch (QOU) during the academic year 2017-2018, who were enrolled in the academic course 'Writing 2'.

\section{Results of the study}

The collected data was analyzed using percentages and analysis of variance. The results have been explained as presented in the tables below:

\subsection{Challenges and difficulties that face students majoring English in learning writing skill.}

What are the challenges and difficulties that face students majoring English in learning writing skill?To answer this question, the researcher prepared a questionnaire and a pre-test for students in both groups to be applied before the treatment of the research. The results of the questionnaire showed that students believe the causes of weakness in writing are attributed to lack of learners' motivation, inadequate time allocated for teaching wring, lack of practice, and lack of teachers' feedback. The results of the pre-test revealed that undergraduate students had several problems in the writing of EFL. They showed language problems at the levels of morphology and syntax and could not remember the appropriate vocabulary items as they know a limited number, and lack of knowledge of the appropriate words and word forms to express themselves.

They showed errors in word order, subject-verb agreement, tenses, pronouns, prepositions, articles, spelling, and sentence structures. Moreover, the findings revealed other writing problems: language problems at the levels of morphology and syntax, lack of ideas and usage errors, cohesion and mechanical mistakes, that is, punctuation and capitalization, lack of several writing development skills, cognitive problems, and organization were all challenges to learners and affect participants' writing skill.

\subsection{Student's Attitude towards ICT and Social Media}

What are the attitudes of undergraduates regarding the use of social media in writing English language at university level? To determine the students' attitude towards ICT and social media, responses of students on Attitude Scale were tabulated and statistically analyzed with the help of SPSS. The total mean scores as well as scores in subscales are presented in table 1. 
Table 1

Mean Value of Students' Scores with Respect to Subscales of Attitude Scale of the Experimental Group

\begin{tabular}{|l|l|l|l|}
\hline Subscale & N & Mean & St. Deviation \\
\hline Motivation to Write & 32 & 4.02 & 0.46 \\
\hline Potential of Technology & 32 & 4.03 & 0.45 \\
\hline Comparative Use of Technology & 32 & 4.06 & 0.48 \\
\hline Creativity & 32 & 4.01 & 0.42 \\
\hline Potential of Development & 32 & 4.70 & 0.47 \\
\hline Overall Attitude & 32 & 4.01 & 0.35 \\
\hline
\end{tabular}

Results as presented in Table 1 reveal that in each subscale, the mean value of scores lies in between 4 and 5 . This may imply that, most of the students strongly agree/ agree with the items given in the attitude scale. Overall attitudes of students are found to be positive towards the use of technology.

4.3 Differences in attitudes and writing proficiency results between the control and the experimental groups

Do students in the experimental group develop their proficiency in writing better than those in the control group with face-to-face traditional teaching method? To answer this question, the researcher compared the results of the pre-test and the post-test. The collected data was computed and analyzed to measure the differences between the results of the control and the experimental groups in both tests. The results are presented in table 2 below:

Table 2

The Differences of the Mean Scores between the Experimental Group and the Control Group on the Pretest

\begin{tabular}{|l|l|l|l|l|l|}
\hline \multicolumn{2}{|l|}{ Experimental group } & \multicolumn{2}{l|}{ Control group } & t-value & \multirow{2}{*}{ Sig } \\
\cline { 1 - 4 } Mean & SD & Mean & SD & & \\
\hline 2.37 & .254 & 2.56 & .232 & -.976 & .331 \\
\hline
\end{tabular}

Results presented in table 2 show that there are no significant differences between the results of the achievements in writing between the control group and the experimental group before conducting the treatment of the study. This result suggests that any significant differences in students' achievement scores in writing after conducting the study are attributed to the effectiveness of using ICT and social media in developing writing proficiency.

To reveal the effect of the ICT and social media on developing students' writing proficiency, the researcher calculated differences between the results of students' achievements in the post-test between the control group and the experimental group after conducting the treatment of the study. The results are presented in table 3 below:

Table 3

The Differences of the Mean Scores between the Experimental Group and the Control Group on the Post-test

\begin{tabular}{|l|l|l|l|l|l|}
\hline \multicolumn{2}{|l|l|}{ Experimental group } & \multicolumn{2}{l|}{ Control group } & \multirow{2}{*}{ t-value } & \multirow{2}{*}{ Sig* } \\
\cline { 1 - 4 } Mean & SD & Mean & SD & & \\
\hline 2.94 & .324 & 2.71 & .293 & 2.27 & $.004^{*}$ \\
\hline
\end{tabular}

The mean score for the experimental group is(2.94), for the control group is (2.71) and the significance level equals $=.004$. This result shows that the differences in the achievement scores between the two groups are significant in favor of the experimental group.

\subsection{The potential achievements of integrating ICT and social media in developing the writing skill}

How do learners in the experimental group perceive the potential achievements of integrating ICT and social media in developing the writing skill? The findings of the open questions indicate that students have positive attitudes towards sing ICT and social media as they think that they can:

- have access to information anytime, and anywhere,

- review and modify their work to improve the quality,

- communicate with other colleagues and present information,

- evaluate their work and compare with others work,

- prompt feedback from instructors, 
- improve efficiency,

- allow students to take greater control of their course activities,

- be creative and take risks,

- gain confidence and independence, and

- develop a daily writing practice and regular habits for deepening a conversation with oneself and with colleagues.

\section{Conclusion}

This research was conducted with an aim to explore undergraduate EFL learners' writing problems, and the effect of ICT and social media in developing positive attitudes and improving students' proficiency in writing English. The study has explored that Palestinian undergraduate EFL learners face various problems in their writing. However, their writing skills can be improved by adapting the new practices and techniques and integrating available ICTs and social media in the process of teaching and learning the English language. The findings of this study revealed that social media plays an important role in writing development of English learners at the university level, and arouse the interest of English learners towards the English language learning, and the English learners may use ICTs and social media for a long enough time, without any hesitation or boredom. Similarly, the findings of the study revealed that the use of social media is easy for young university level learners as compared to books, or other text materials while going to library and get books related to writing development. The learners may use social media sources like Facebook, Twitter, You-tube, what's App, and other tools of social media to improve their English language and writing skill through digital media by developing a daily writing practice and regular habits for deepening a conversation with oneself and with colleagues.

\section{References}

Adas, D., \& Bakir, A. (2013). Writing difficulties and new solutions: blended learning as an approach to improve writing abilities. International Journal of Humanities and Social Science, 3(9), 254-266.

Akinwamide, Timothy. (2012). Imperatives of Information and Communication Technology (ICT) for Second Language Learners and Teachers. Canadian Center of Science and Education, 5(1), 44-48.

Alfahadi , Abdulrahman. The Role of Social Media Sites in the Enhancement of English Language Learning at the University of Tabuk. International Journal of English and Education Volume:6, Issue:3, July 2017

Alfaki, Ibrahim Mohamed..University Students' English Writing Problems: Diagnosis and Remedy. Nile Valley University Atbara, Sudan. International Journal of English Language Teaching Vol.3, No.3, pp.40-52, May 2015.

Bancha, W. (2013). What causes spelling errors of Thai EFL students. ARECLS, 10, 107-129.

Barri, Sabreen, (2017). The Influence of Multimedia on Improving the Sixth Graders' English Vocabulary in Nablus city Private Schools. (Unpublished master's thesis). An-Najah National University. Nablus. Palestine.

Bianchi, Abdel Razeq, 2016. The English Language Teaching Situation in Palestine in English Language Education Policy in the Middle East and North Africa Springer International Publishing AG 2017

Dabbagh, Nada, . Kitsantas, Anastasia. (2011) "Personal Learning Environments, social media, and self-regulated learning: A natural formula for connecting formal and informal learning." The Internet and Higher Education, Vol. 15, No. 1. (January 2012), pp. 3-8

Dajani, Dua. 2014. Implementing the First Palestinian English Language Curriculum: A Need for Teacher Employment.file:///D:/Documents/Downloads/MJES-2009.pdf

Dar, M. F., \& Khan, I.(2015). Writing anxiety among public and private sectors Pakistaniundergraduate university students.Pakistan Journal of Gender Studies, 10 (1), 121- Available from: https://www.researchgate.net/publication/311669829_ESL_Learners'_Writing_Skills_Problems_Factors_and_ Suggestions

Dhanya G. 2016. Influence of Social Media on English Language Learning Journal of English Language and Literature (JOELL). Available from: http://joell.in/wp-content/uploads/2016/03/INFLUENCE-OF-SOCIAL-MEDIA.pdf

Fareed, Muhammad,. Ashraf, Almas,. and Bilal, Muhammad 2016. ESL Learners' Writing Skills: Problems,... (PDF Download Available). Available from: https://www.researchgate.net /publication/311669829_E SL_Learners'_Writing_Skills_Problems_Factors_and_Suggestions [accessed May 31 2018].

Farrah. M., \& Tushyeh. H. Enhancing the English Reading and Writing Skillsof Palestinian English Majors by Using CALL. Hebron University Research Journal.Vol.(5), No.(2), pp.(259-282), 2010 
Genlott, A., \& Grönlund, A. Improving literacy skills through learning reading by writing. Computers \& Education. Volume 67, September 2013, Pages 98-104

Ghasemi, Babak. Hashemi, Masoud. 2011. ICT: Newwave in English language learning/teaching. Procedia Social and Behavioral Sciences 15 (2011) 3098-3102

Greenhow\& Lewin 2015. Social media and education: Reconceptualizing the boundaries of formal and informal learning

Gupta, Priyanka 2015 Importance of Social Media in Higher Education Available from http://edtechreview .in/trendsinsights/insights/2041-social-media-in-higher-education

Jiménez, William Ch. 2014. The Use of ICTs in the BA in English Teaching, Available from: http://www.scielo.sa.cr/pdf/aie/v14n1/a06v14n1.pdf

Jung, Sei-Hwa. 2006. The Use of ICT in Learning English as in International Language. https://drum.lib.umd.edu/bitstream/handle/1903/3885/umi-umd3733.pdf;jsessionid=27193DBEA240CC645E63DE99DB486C93? sequence=1

Junco, R., and S. R. Cotton. 2013. "No A 4 U: The relationship between multitasking and academic performance." Computers \& Education 59: 505-514.

Khan, Ayaz\& Faheem, 2016 The Role of Social Media in Development of English Language Vocabulary at University Level.International Journal of Academic Research in Business and Social Sciences 2016, Vol. 6, No. 12

Kirschner, A. P., and A. C. Karpinski. 2010. Facebook and Academic Performance.Computers in Human Behavior 26: 1237-1245.

Kurzweil Educational Systems, (2004). Using Technology as a Solution for English Language Learners in Higher Education. Available from: https://www.kurzweiledu.com/files/kurzweil-3000-ell-higher-ed.pdf

Nagarathinam, D. Ramkumar, V. and Vani, R. 2016. New Perspectives in ELT Innovative Tactics in English Language Teaching. Available from: http://www.languageinindia.c om/april2016/thenis minar201 6volume.pdf

Nomass, Bassma. (2013). The Impact of Using Technology in Teaching English as a Second Language. English Language and Literature Studies, 3(1), 111-116.

Pim, Chris. 2013. Emerging technologies, emerging minds: digital innovations within the primary sector. In Innovations in learning technologies for English language teaching. British Council.

Prakash, Anjlee . Professional Learning: Empowering Educators to Transform Learning and Teaching. Available from:https://www.intel.com/content/dam/www/public/us/en/documents/education/education-transforma tionnext-generation-chap-5.pdf

Purcell, K. , Buchanan, J., and Friedrich, L., (2013). The Impact of Digital Tools on Student Writing and How Writing is Taught in Schools. Available from: http://www.pewinternet.org/files/old-media/Files/Reports/2013/PIP_NWP\%20Writing\%20and\%20Tech.pdf

Rajesh, Sreeja. Michael, Jithin. Effectiveness of Social Media in Education International Journal of Innovative Research in Advanced Engineering (IJIRAE) ISSN: 2349-2163 Issue 10, Volume 2 (October 2015)

Ramahi , Hanan, (2015). Education in Palestine: Current Challenges and Emancipatory Alternatives A study.

Sakkir, G. , Rahman Q., \& Salija, K., (2016). Students' Perception on Social Media in Writing Class at STKIP Muhammadiyah Rappang, Indonesia. Avalable from: file:///D:/Documents/Downloads/57669-212147-1PB.pdf

Sámano, Andrea Preciado. 2014. Learning English in the social media: A resource to keep learning outside the classroom: Available from:

https://www.researchgate.net/publication/266853314

Slechtova, Pavla. 2015. Attitudes of Undergraduate Students to the Use of ICT in Education. Avalable from: https://www.sciencedirect.com/science/article/pii/S1877042815002487

Sumathi, S., Phil, M., 2016. Innovative Tactics in English Language Teaching. Available from: http://www.languageinindia.com/april2016/sumathi.pdf

Vervaart, Peter 2013. Role of Social Media and the Internet in Education. The Journal of the International Federation of Clinical Chemistry and Laboratory Medicine. Available from: https://www.ncbi.nlm.nih.gov/pmc/articles/PMC4975239/

Wilson, Mark. 2015. Investigating the effectiveness of modern learning environments on improving student learning and achievement. Available from:

Documents/Downloads/Mark\%20Wilson\%20Sabbatical\%20Report\%202015\%20\%20Investigating\%20the\%2 0Effectiveness\%20of\%20Modern\%20Learning\%20Environments\%20\%20(1).pdf 